\title{
Proteolytic Processing of Human Brain Alpha Spectrin (Fodrin): Identification of a Hypersensitive Site
}

\author{
Alan S. Harris and Jon S. Morrow \\ Department of Pathology, Yale University School of Medicine, New Haven, Connecticut 06510
}

The processing of brain spectrin (fodrin) by calcium-dependent proteases at the postsynaptic membrane has been postulated to be one of the central molecular mechanisms underlying long-term potentiation (LTP). The effect of such processing on the structure and function of brain spectrin, and on spectrin's ability to organize or otherwise regulate receptor function remains unclear. To address these issues, human and bovine brain spectrin were digested under mild conditions with several proteases, and the resulting cleavage fragments analyzed by 2-dimensional chymotryptic ${ }^{125}$ | peptide mapping. These studies identify an underlying protease-resistant domain structure reminiscent of, yet distinctly different from, human erythroid spectrin. More importantly, fodrin is unusual for the presence of a single, proteolytically hypersensitive site in the center of the alpha subunit, which is the favored site of action by many proteases, including the calcium-dependent neutral proteases. This proteolytically hypersensitive site is a unique feature of alpha nonerythroid spectrin since it is absent from human erythrocyte spectrin and appears to be the site at which the molecule is processed in vivo. In addition, on the basis of gel overlay techniques, it appears that the hypersensitive site is also the site at which calmodulin binds to the alpha-subunit in a calcium-dependent manner. These studies thus establish at the molecular level 2 calcium-dependent mechanisms by which brain spectrin function might be regulated and provide a conceptual and methodological framework for further investigation into the function of this important molecule.

The nonerythroid spectrins (fodrins) have emerged as an important class of multifunctional proteins that appear to be involved with the organization and stabilization of the plasma membrane (for reviews, see Bennett, 1985; Marchesi, 1985). The most studied member of this class is the spectrin derived from brain. Many of our concepts regarding this protein have been based on analogy with mammalian erythrocyte spectrin. Both brain and erythrocyte spectrin are viewed as heterodimers composed of 2 nonidentical subunits; and both have been found

\footnotetext{
Received Sept. 1, 1987; revised Dec. 7, 1987; accepted Dec. 10, 1987.

We would like to thank Dr. Dorothy Croall for her generous gift of the purified calcium-dependent protease and for her advice and encouragement. This work was supported by grants from the National Institutes of Health HL28560 (J.S.M.) and NS24414-01 (A.S.H.); a basic research grant from The March of Dimes Foundation (1-982) (J.S.M.); a grant from the Wills Foundation (J.S.M.), and a postdoctoral fellowship from The Muscular Dystrophy Association of America (A.S.H.), and by NIH training grant GM 07562-09.

Correspondence should be addressed to Jon S. Morrow at the above address.

Copyright (C) 1988 Society for Neuroscience $0270-6474 / 88 / 072640-12 \$ 02.00 / 0$
}

to self-associate to at least the tetrameric state and bind actin, ankyrin, and calmodulin (for reviews, see Goodman and Zagon, 1984; Bennett, 1985; Marchesi, 1985).

There are, however, many differences between the mammalian brain and erythrocyte spectrins. These 2 proteins share only limited immunologic cross-reactivity (see Harris et al., 1985, 1986, and references therein) and are only about $53 \%$ identical, based on the limited protein and cDNA sequencing data available (Speicher and Marchesi, 1984; Birkenmeier et al., 1985; Curtis et al., 1985; A. S. Harris, S. Keithan, D. W. Speicher, and J. S. Morrow, unpublished observations). Reflecting this structural dissimilarity, the 2 protcins also differ substantially in their function, as measured by both in vitro and in vivo assays. Since nonerythroid spectrin appears to be asymmetrically distributed in some cells, and even cleared from large areas of the plasma membrane, it cannot, like erythrocyte spectrin, be necessary for global support of the plasma membrane (see Morrow, 1984; Harris et al., 1985, and references therein). Correspondingly, unlike erythroid spectrin, brain spectrin has been reported to interact with microtubules (Ishikawa et al., 1983; Fach et al., 1985), synapsin I (Baines and Bennett, 1985) and to bind calmodulin on its alpha $(240 \mathrm{kDa})$ subunit (Glenney et al., 1982; Harris et al., 1985). It does not self-polymerize to oligomeric forms larger than tetramer, a characteristic of erythrocyte spectrin (Harris et al., 1985).

In the nervous system, fodrin appears to play a particularly important, albeit poorly understood, role. Specific isoforms are asymmetrically distributed within cells (Nelson and Lazarides, 1983; Shile et al., 1985; Riederer et al., 1986; Siman et al., 1987) and with specific neurotransmitter receptors (Bloch and Morrow, 1987). Proteolytic processing of fodrin by calciumdependent proteases also correlates closely with enhanced glutamate receptor exposure in hippocampal neurons, with the development of long-term potentiation (LTP) in vitro, and with maze-learning in rats (Baudry et al., 1983; Lynch and Baudry, 1984; Siman et al., 1984, 1985). Thus, it has been postulated that fodrin processing may be a central molecular mechanism underlying the development and/or maintenance of long-term memory (Lynch and Baudry, 1984). The mechanisms responsible for these processes remain uncertain.

We now report a detailed characterization of the proteolytically resistant domain structure of human brain alpha spectrin and identify a unique proteolytically hypersensitive site in the center of alpha fodrin at which the protein is preferentially cleaved both in vitro and in vivo. This site is also shown to be involved with the calcium-dependent binding of calmodulin. These studies establish at the molecular level 2 calcium-dependent mechanisms by which brain spectrin function may be regulated. 


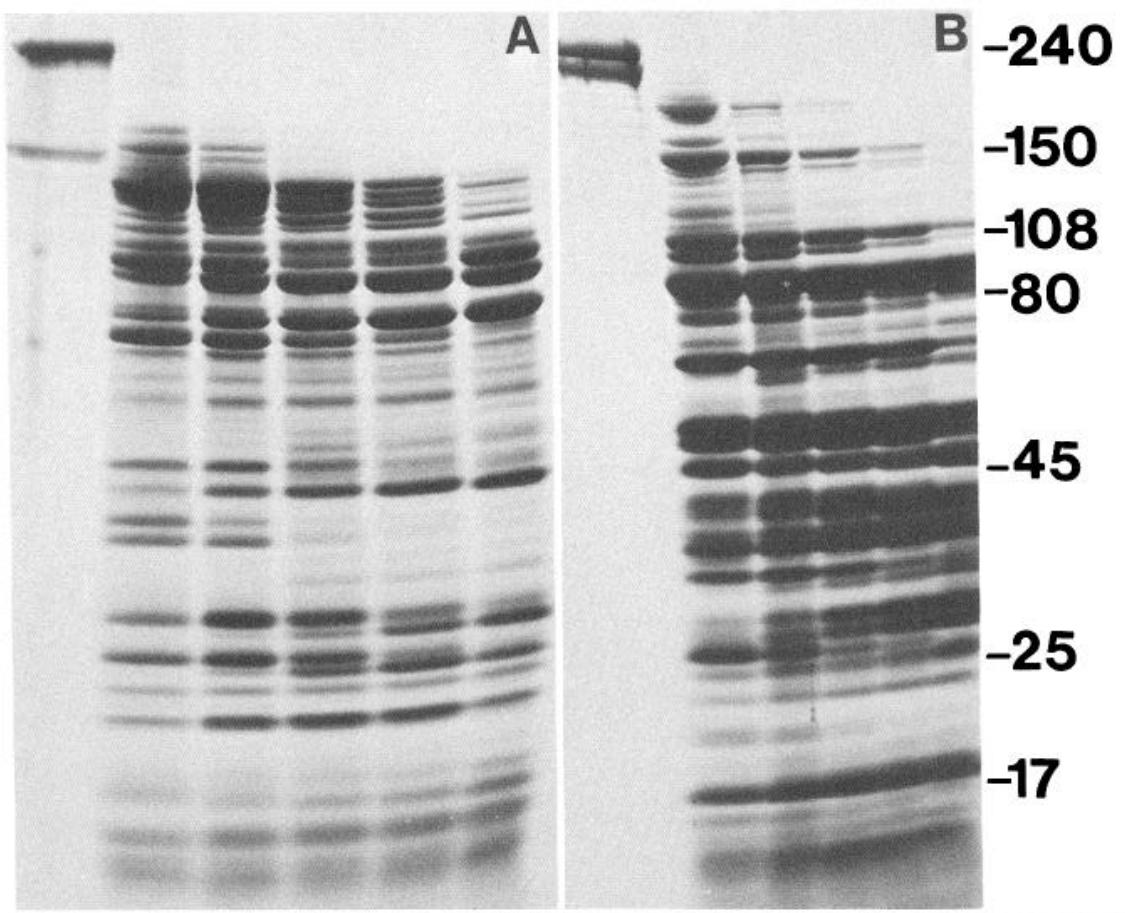

C

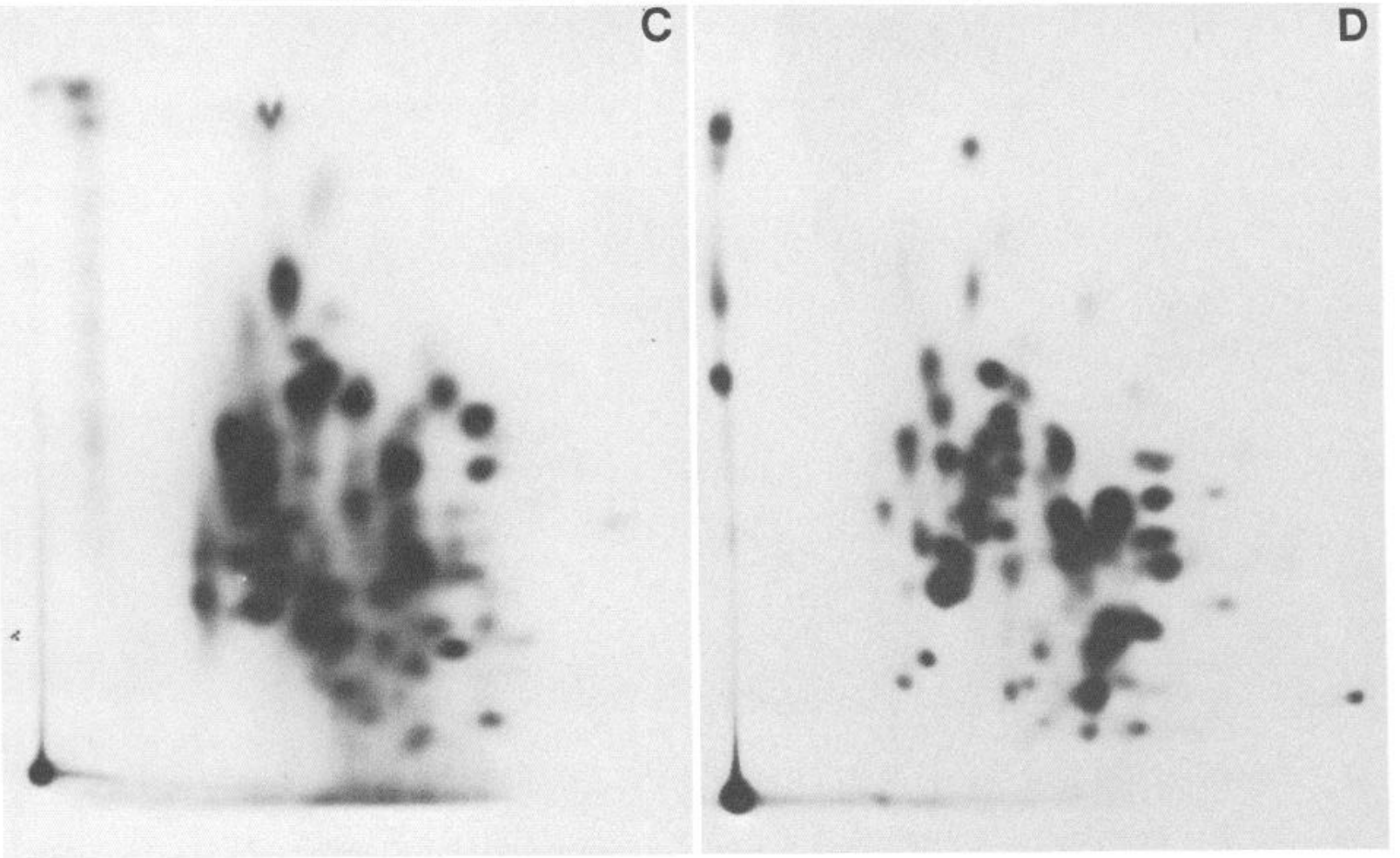

Figure 1. Restricted proteolysis of human brain $(A)$ and erythrocyte $(B)$ spectrin with trypsin demonstrated the reduced proteolytic susceptibility of brain spectrin. Digestion conditions were enzyme : substrate $1: 1.5$ (mol:mol), $0^{\circ} \mathrm{C}$, for various times. Lanes left to right correspond to the following digestion times: $0 \mathrm{hr}$ (no enzyme), 1, 2, 4, 8, and $24 \mathrm{hr}$. The amount of protein loaded was $20 \mu \mathrm{g}$ in the first lanes, and $100 \mu \mathrm{g}$ for all other lanes. SDS-PAGE in a linear 7-15\% acrylamide gradient. Two-dimensional ${ }^{125}$ I peptide mapping of human brain $(C)$ and erythrocyte $(D)$ spectrin also demonstrated a lack of recognizable homology between these 2 proteins. [Data $(D)$ from Speicher et al., 1982, used with permission.]

\section{Materials and Methods}

Preparation of proteins. Human erythrocyte spectrin was prepared from fresh erythrocyte ghosts by extraction in $0.1 \mathrm{~mm}$ EDTA, $\mathrm{pH} \mathrm{9.0,} \mathrm{at}$ $37^{\circ} \mathrm{C}$, followed by gel filtration on Sepharose CL-4B (Pharmacia) according to established procedures (Morrow and Marchesi, 1981). Human brain spectrin was prepared as described (Harris et al., 1986), with the following modifications. The final step in the purification was ionexchange chromatography at $4^{\circ} \mathrm{C}$ on a $1 \times 10 \mathrm{~cm}$ column of AccellQMA (Millipore Corp., Milford, MA) using a $170 \mathrm{ml}$ linear gradient of 25-750 mm NaCl in $20 \mathrm{~mm}$ Tris- $\mathrm{HCl}, 0.5 \mathrm{~mm}$ EDTA, $1 \mathrm{~mm}$ 2-mercaptoethanol, $\mathrm{pH}$ 7.8. The fractions containing purified brain spectrin (monitored by $\mathrm{A}_{280}$ and SDS-PAGE) were concentrated by vacuum dialysis versus $20 \mathrm{~mm}$ Tris- $\mathrm{HCl}, 1 \mathrm{~m} \mathrm{NaCl}, 0.5 \mathrm{~mm}$ EDTA, $1 \mathrm{~mm}$ 

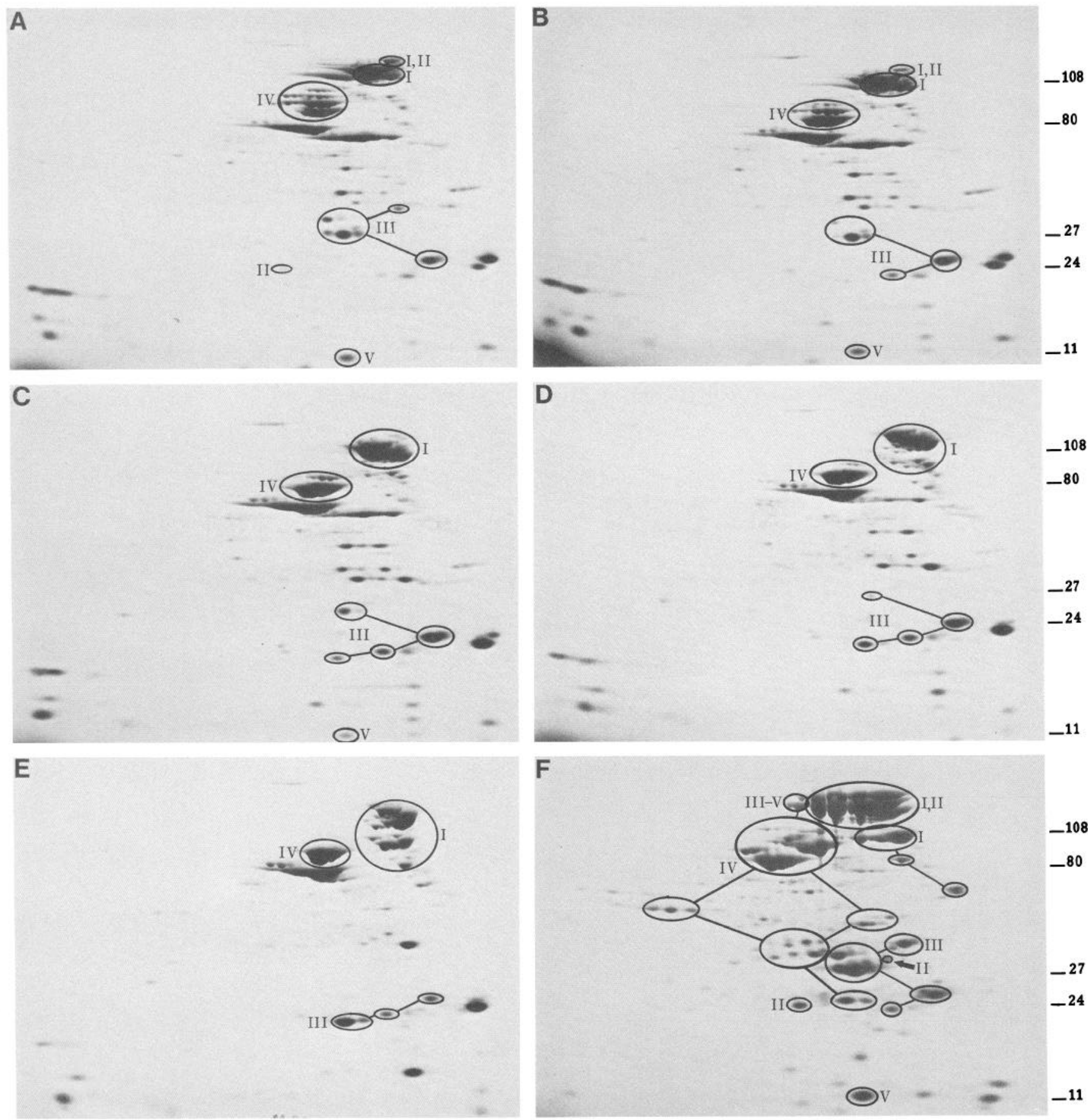

Figure 2. Time course digestion of human brain spectrin with trypsin demonstrated the variable proteolytic sensitivity of the alpha subunit domains. Only peptides derived from the alpha subunit are labeled in these figures. Domains and some of the major proteolytic products are indicated. The $1 \mathrm{hr}$ digest of brain spectrin heterodimer $(A)$ displayed all 5 unique domains (labeled I-V), while further digestion of the heterodimer $(B-E)$ demonstrated the relative proteolytic sensitivity of these domains. Most of the unidentified peptides on the gels $A-E$ arise from the beta subunit (data not shown). Digestion conditions: $A-E$, intact human brain spectrin, $210 \mu \mathrm{g}$, enzyme : substrate, $1: 1(\mathrm{~mol}: \mathrm{mol}), 0^{\circ} \mathrm{C}$, for $1(A), 2(B)$, $4(C), 8(D), 24(E) \mathrm{hr}$. F, Alternatively, $500 \mu \mathrm{g}$ of the purified alpha subunit alone was digested as above at an enzyme: substrate ratio of 1:1 (mol: $\mathrm{mol}), 0^{\circ} \mathrm{C}, 1 \mathrm{hr}$. Additional peptides are apparent on this gel $(F)$ compared to $(A)$ since 5 times as much alpha spectrin was loaded and because new cleavages occur when the alpha subunit is digested in the absence of the beta subunit (see text). Despite the enhanced load on this gel $(F)$, peptides derived from the beta-subunit are conspicuously absent (cf. noncircled peptides in gel $A$ with gel $F$ ). All digestions were analyzed by 2-dimensional IEF/SDS-PAGE using a 7-15\% linear acrylamide gradient in the second dimension and are stained with Coomassie blue.

2-mercaptoethanol, $\mathrm{pH} 8.0$, and stored after dialysis against digestion buffer $(20 \mathrm{~mm}$ Tris- $\mathrm{HCl}, 25 \mathrm{~mm} \mathrm{NaCl}, 0.5 \mathrm{~mm}$ EDTA, $1 \mathrm{~mm}$ 2-mercaptoethanol, $\mathrm{pH}$ 8.0). The isolated alpha subunit was prepared using hydroxyapatite chromatography in the presence of $7 \mathrm{M}$ urea (Davis and
Bennett, 1983). Calmodulin was prepared from frozen and fresh bovine brain by the method of Burgess et al. (1980).

Protein digestions. Brain spectrin was cleaved at cysteine residues with NTCB (Eshdat and Lemay, 1979). Brain spectrin at $1 \mathrm{mg} / \mathrm{ml}$ in $7.5 \mathrm{M}$ 

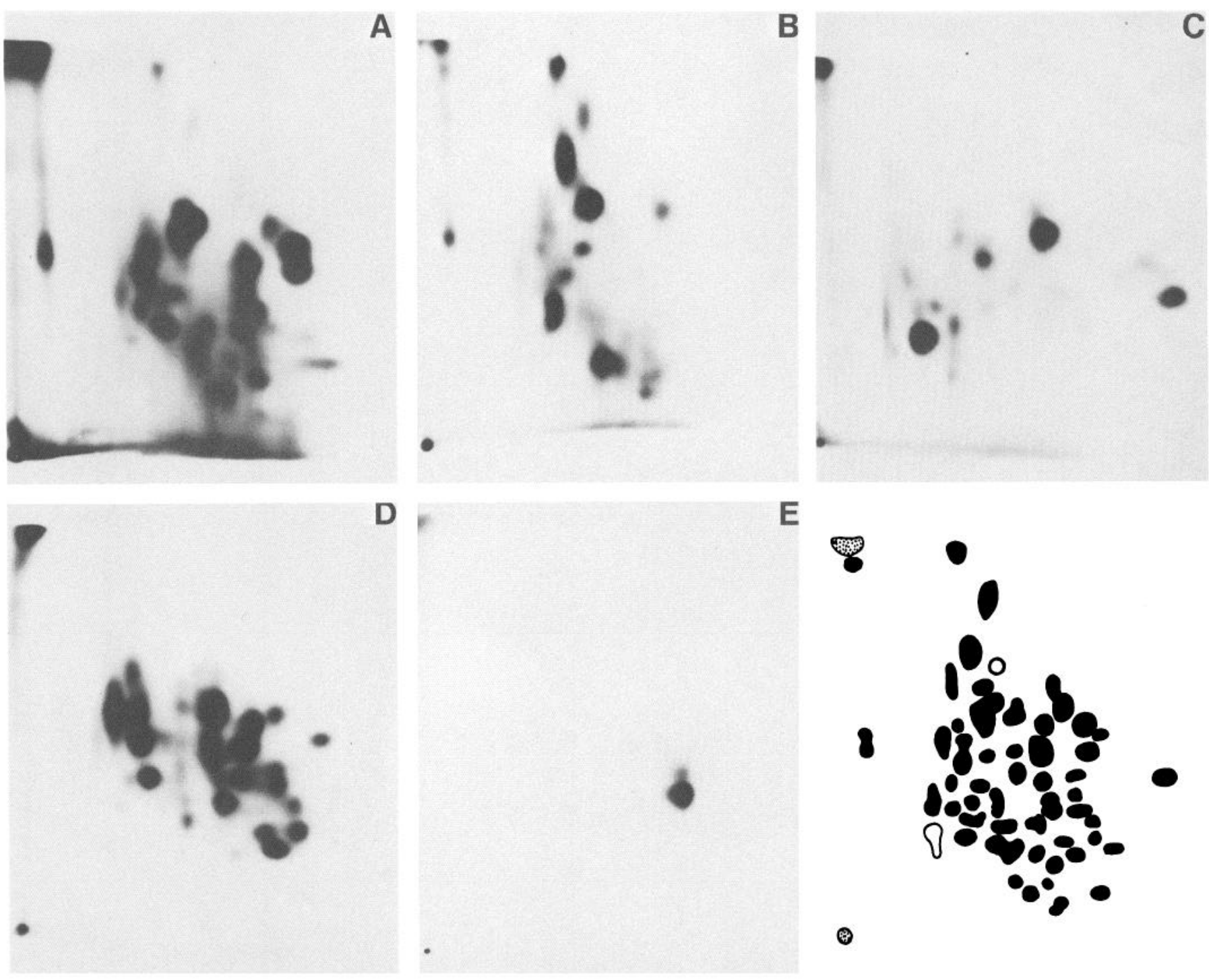

(ㄱ)

Figure 3. Two-dimensional peptide mapping of tryptic peptides from brain alpha spectrin identified 5 unique, proteolytically defined domains. Autoradiograms of the maps are shown. The apparent molecular weights of the domains mapped were $(A)$ domain $\mathrm{I}, 108 \mathrm{kDa} ;(B)$ domain II, 32 $\mathrm{kDa} ;(C)$ domain III, $35 \mathrm{kDa} ;(D)$ domain IV, $80 \mathrm{kDa} ;(E)$ domain V, $11 \mathrm{kDa}$. $F$, A diagrammatic interpretation of the 5 alpha domain peptide maps and their relationship to the peptide map of the intact alpha subunit. The 5 domains $(A-E)$ account for more than $95 \%$ of the peptides on the intact alpha subunit map, as shown in $F$. The dotted spots in $F$ represent the origin and the radioactive material that migrates with the solvent front in all maps. Open spots represent peptides in the map of the intact molecule that could not be accounted for by the 5 domain maps; the filled spots are peptides present in both the parent map and in one or more of the domain maps.

guanidine- $\mathrm{HCl}$ (or $8 \mathrm{~m}$ urea), $200 \mathrm{~mm}$ Tris- $\mathrm{HCl}, 1$ mм EDTA, pH 8.0 , was reacted with $513 \mathrm{~mm}$ NTCB for $1 \mathrm{hr}$ at room temperature. Cleavage was initiated after the $\mathrm{pH}$ was raised to 9.0 with $0.5 \mathrm{M}$ Tris, $\mathrm{pH} 12$, followed by incubation at $37^{\circ} \mathrm{C}$ for $16 \mathrm{hr}$. The reaction was terminated by the addition of 2 -mercaptoethanol to $25 \mathrm{~mm}$, and the material was dialyzed versus several changes of $10 \mathrm{~mm}$ Tris- $\mathrm{HCl}, \mathrm{pH} 8.0,0.5 \mathrm{~mm}$ EDTA, $1 \mathrm{~mm}$ 2-mercaptoethanol and lyophilized. Proteolytic digests, except as noted otherwise, were done in digestion buffer at protein concentrations of $0.4-1.5 \mathrm{mg} / \mathrm{ml}$ under temperature-controlled conditions at 0 or $23^{\circ} \mathrm{C}$. Trypsin (TPCK-trypsin, Worthington), alpha-chymotrypsin (Worthington), endoprotease Lys-C (Boehringer-Mannheim), or $S$. aureus V-8 endoprotease Glu-C (Boehringer-Mannheim) at $1 \mathrm{mg} / \mathrm{ml}$ was added to the protein at the enzyme: substrate ratios indicated. Calcium-dependent proteases I and II (generously provided by Dr. Dorothy Croall, University of Texas, Dallas) were used at enzyme : substrate ratios of $1: 10$ to $1: 25$ (mol:mol) at free calcium concentrations of 0.1 and $0.7 \mathrm{~mm}$ for CDP I and CDP II, respectively. The preparation of these proteases has been previously described (Croall et al., 1986). After various times, digests were terminated by adding DFP to a final concentration of $10 \mathrm{~mm}$, followed by either the addition of solubilizing buffer for SDS-PAGE or by lyophilization for IEF/SDSPAGE. Some tryptic digestions were terminated by the addition of 2-fold (mol:mol) pancreatic trypsin inhibitor over trypsin followed by DFP to $10 \mathrm{~mm}$, and lyophilization after $6-30 \mathrm{hr}$ incubation at $0^{\circ} \mathrm{C}$. Calcium-dependent protease digestions were terminated with the addition of DFP and EGTA, both to a final concentration of $10 \mathrm{~mm}$.

Peptide mapping, gel electrophoresis, and other procedures. Two-dimensional cellulose ${ }^{125} \mathrm{I}$ peptide mapping of Coomassie blue-stained peptides was performed using established procedures (Elder et al., 1977) with modifications as described (Speicher et al., 1982). Briefly, proteins or peptides were cut from polyacrylamide gels and labeled with ${ }^{125}$ I using chloramine-T. After removal of the free ${ }^{125} \mathrm{I}$, the gel slices were digested with alpha-chymotrypsin (Worthington, $50 \mu \mathrm{g}$ in $50 \mathrm{~mm}$ $\mathrm{NH}_{4} \mathrm{HCO}_{3}$ ) for $24 \mathrm{hr}$ at $37^{\circ} \mathrm{C}$. Peptides were recovered in the liquid phase and lyophilized. The peptides were dissolved in electrophoresis buffer, spotted onto cellulose plates, and separated by high-voltage electrophoresis in the horizontal dimension and by ascending liquid chromatography in the vertical dimension. Peptide maps were visualized by autoradiography at $-70^{\circ} \mathrm{C}$ using Kodak XRP film and fluorescent intensifying screens. SDS-PAGE and 2-dimensional IEF/SDS-PAGE 

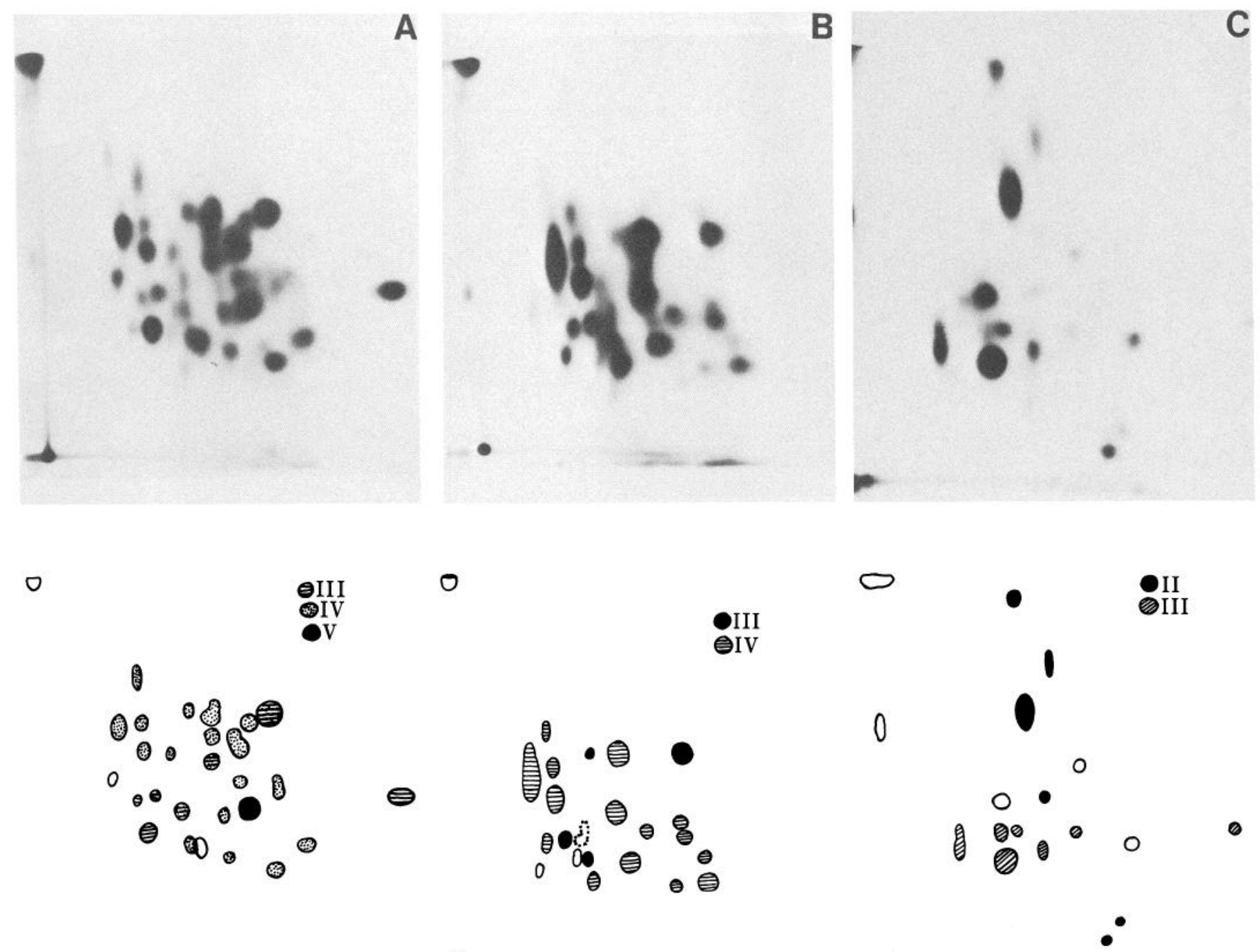

○

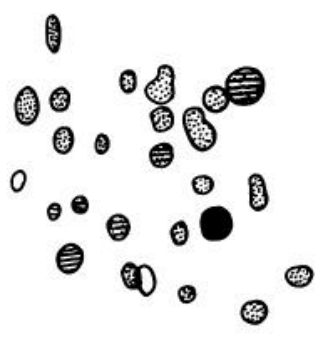

0

Figure 4. Two-dimensional peptide mapping of overlap peptides generated by alternate cleavage methods determined the linear sequence of the tryptic domains. Top, Autoradiograms of the 2-dimensional peptide maps of the overlap fragments. Bottom, Diagrammatic interpretation of the peptide maps of the overlap peptides demonstrating their relationship to domains identified in Figure 3. Open spots represent peptides not found in the domain maps of the juxtaposed domains, while filled, striped, or stippled spots are found in the maps of the indicated domains. A, $145 \mathrm{kDa}$ peptide found as a natural product (or generated with chymotrypsin, Figs. 5 and $6 A ; B, 70 \mathrm{kDa}$ NTCB peptide; $C, 45 \mathrm{kDa}$ NTCB peptide.

were performed by the methods of Laemmli(1970) and O'Farrell(1975), respectively, with minor modifications (Harris et al., 1986). All 2-dimensional gels are presented with the basic region of the IEF dimension to the left. Proteins were visualized by Coomassie blue staining. Protein concentrations were estimated by the method of Lowry et al. (1951). Calmodulin was labeled with ${ }^{125}$ I using immobilized lactoperoxidase and glucose oxidase (Enzymobeads, Bio-Rad) as previously described (Anderson and Morrow, 1987). Calmodulin overlays were performed as previously described (Carlin et al., 1983).

\section{Results}

Brain spectrin is overall more resistant to proteolysis than erythrocyte spectrin

Human brain and erythrocyte spectrin were digested under identical conditions with limited quantities of trypsin. The products of cleavage of human brain spectrin and human erythrocyte spectrin are shown in Figure 1. Although neither protein remained intact under these digestion conditions, at corresponding digestion times, the majority of the cleavage products of brain spectrin were larger than those from erythrocyte spectrin.
This persistence of larger fragments suggests a decreased susceptibility of the brain protein to enzymatic digestion. Separate experiments (data not shown) indicated that this decreased proteolytic susceptibility of the brain protein relative to human erythrocyte spectrin is even more accentuated at higher temperatures. A comparison of the 2-dimensional peptide maps of the alpha subunits of human brain and erythrocyte spectrin (Fig. $1, C, D)$ also demonstrated large differences between these 2 proteins. Thus, while human brain and erythrocyte spectrin share limited sequence homology (Speicher and Marchesi, 1984; Curtis et al., 1985; A. S. Harris, S. Keithan, D. W. Speicher, and J. S. Morrow, unpublished observations), they appear to differ substantially in overall compactness of their secondary, tertiary, and/or quaternary structure.

\section{Alignment of the proteolytic peptides: a human brain alpha spectrin domain map}

As shown below, brain alpha spectrin was found to contain a site at which protease digestion was most prominent in vitro. 
In order to locate this site within the subunit, a characterization of the various cleavage fragments was necessary. Digestion of brain spectrin with trypsin for various periods of time was employed to determine the nature of the proteolytic-resistant domains. As shown in Figure 2, prominent digestion fragments remained after $1 \mathrm{hr}$ of digestion $(A)$; those arising from the alpha subunit were most evident when the isolated alpha-subunit was digested $(F)$. Those peptides that remained after $24 \mathrm{hr}$ of digestion with trypsin and were derived from the alpha subunit as determined by peptide mapping were considered prime candidates for proteolytically resistant domains. Mapping of the peptides cut from the gel shown in Figure $2 E$ revealed 3 unique groups of peptides, labeled I, III, and IV. (The nomenclature of the domains is based on their order within the alpha-subunitsee below.) The large group of peptides labeled I contained the parent peptide of that domain $(108 \mathrm{kDa})$, as well as several proteolytic products. The relationship of the peptides of lower molecular weight to the parent peptide was established by peptide mapping. Domain III, present as a single peptide of $24 \mathrm{kDa}$, was the last stable peptide in a cascade evident in the other gels (Fig. 2, $A-D$ ). The largest peptide found in this cascade was of $35 \mathrm{kDa}$ in the $1 \mathrm{hr}$ digest (Fig., 2, $A, F$ ) and was therefore considered the parent peptide. The domain labeled IV was a very stable domain that was derived from a series of 5 similar peptides noted in the gel shown in Figure $2 A$. All 3 domains found in the $24 \mathrm{hr}$ digest had unique peptide maps (Fig. 3) and thus constituted nonoverlapping parts of the molecule. Conversely, domain II was found in negligible yield after a $1 \mathrm{hr}$ tryptic digestion of intact brain spectrin. Since the peptide maps of the large fragments labeled I,II in the gels shown in Figure 2, $A, B$, and $F$, contained the maps of both domain I and domain II (Fig. 6), it is clear that domain II was digested into smaller peptides soon after it was cleaved from the large I,II peptide. After a $1 \mathrm{hr}$ tryptic digestion of the isolated alpha-subunit, the yield of domain II was increased substantially (Fig. $2 F$ ). Since 2 peptides were found in this digest with similar peptide maps, the largest $(32 \mathrm{kDa})$ was considered the parent peptide, although the smaller $24 \mathrm{kDa}$ peptide was more abundant. Domain V (11 $\mathrm{kDa}$ ) was assigned since it was stable cleavage fragment from the tryptic fragment T95 (domains IV and V). Domain IV was thus assigned as the T80 fragment as depicted in Figure 9. All of the prominent peptides in the digest of the isolated alphasubunit (Fig. $2 F$ ) can be accounted for by the 5 domains of the proposed model (Fig. 9), and the aggregate molecular weight of the domains is similar to the molecular weight of the intact alpha subunit. The prominent unlabeled peptides in Fig. 2, A$E$, are proteolytic products of the beta-subunit.

\section{Absence of the beta-subunit alters the tryptic digestion of alpha spectrin}

Several peptides appeared in the tryptic digest of the isolated alpha-subunit (Fig. $2 F$ ) that were not seen in the digest of the intact heterodimer (Fig. 2, $A-E$ ). The domain identity of the prominent fragments in this digestion has been noted (Fig. $2 F$ ). Domains I and III showed increased degradation in the absence of the beta-subunit, but the peptides generated were identical when compared with the digestion of intact brain spectrin under identical conditions (Fig. 2A). However, new fragments were generated by internal cleavage of domain IV in the absence of the beta-subunit. This result was in striking contrast to erythrocyte spectrin, which yielded identical peptides upon tryptic digestion of the isolated monomer subunits or the intact mol-

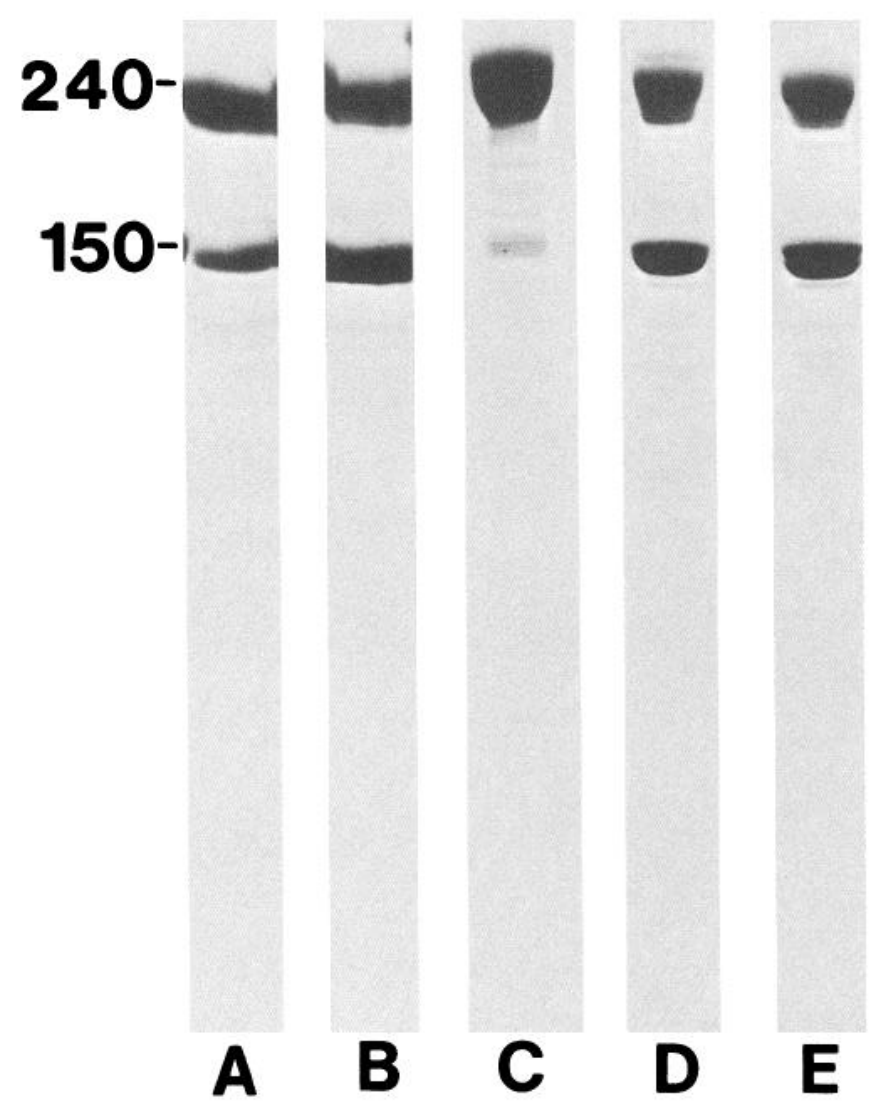

Figure 5. Human and bovine brain alpha spectrin are cleaved at the hypersensitive site by calcium-dependent protease I. Human (lanes $A$ and $B$ ) and bovine (lanes $C-E$ ) fodrin was incubated in the presence of $200 \mu \mathrm{M}$ calcium for $30 \mathrm{~min}$ at $23^{\circ} \mathrm{C}$ in the absence (lanes $A$ and $C$ ) or the presence (lanes $B$ and $D$ ) of calcium-dependent protease $I$ at an enzyme : substrate ratio of $1: 25$ (mol:mol). The increase in the products at $150 \mathrm{kDa}$ is due to cleavage of the alpha-subunit exclusively. Lane $E$ was digested with chymotrypsin [enzyme: substrate, 1:250 (mol:mol)], demonstrating the similar site of cleavage of the alpha-subunit and no detectable cleavage of the beta-subunit (see Fig. $6 B$ ). Coomassie blue stain of 5-15\% gradient acrylamide SDS gels.

ecule (Speicher et al., 1982). Thus, unlike erythroid spectrin, quaternary interactions between the alpha- and beta-subunits of brain spectrin alter the proteolytic susceptibility of the alphasubunit. Additional studies will be required to further define the precise sites of interaction between the subunits and whether there is also an effect of the alpha-subunit upon the digestion of the beta-subunit.

\section{Peptide mapping of the alpha-subunit domains and overlap peptides}

Peptide mapping of the domains depicted in Figure 2 demonstrated that the alpha-subunit is comprised of 5 unique, proteolytically defined domains (Fig. 3). The relationship of the domains to the alpha-subunit was determined by comparison of the maps of the peptides in Figure 2 and the maps of the overlapping peptides (Fig. 4) with the parent alpha-subunit peptide map. Although it is apparent that some spots were shared by several domains, the intensity of these spots collectively was similar to that seen in the intact alpha-subunit map (Fig. 1). Additional proof that the shared spots were fortuitous and not due to cross-contamination is presented later (Fig. 6). 

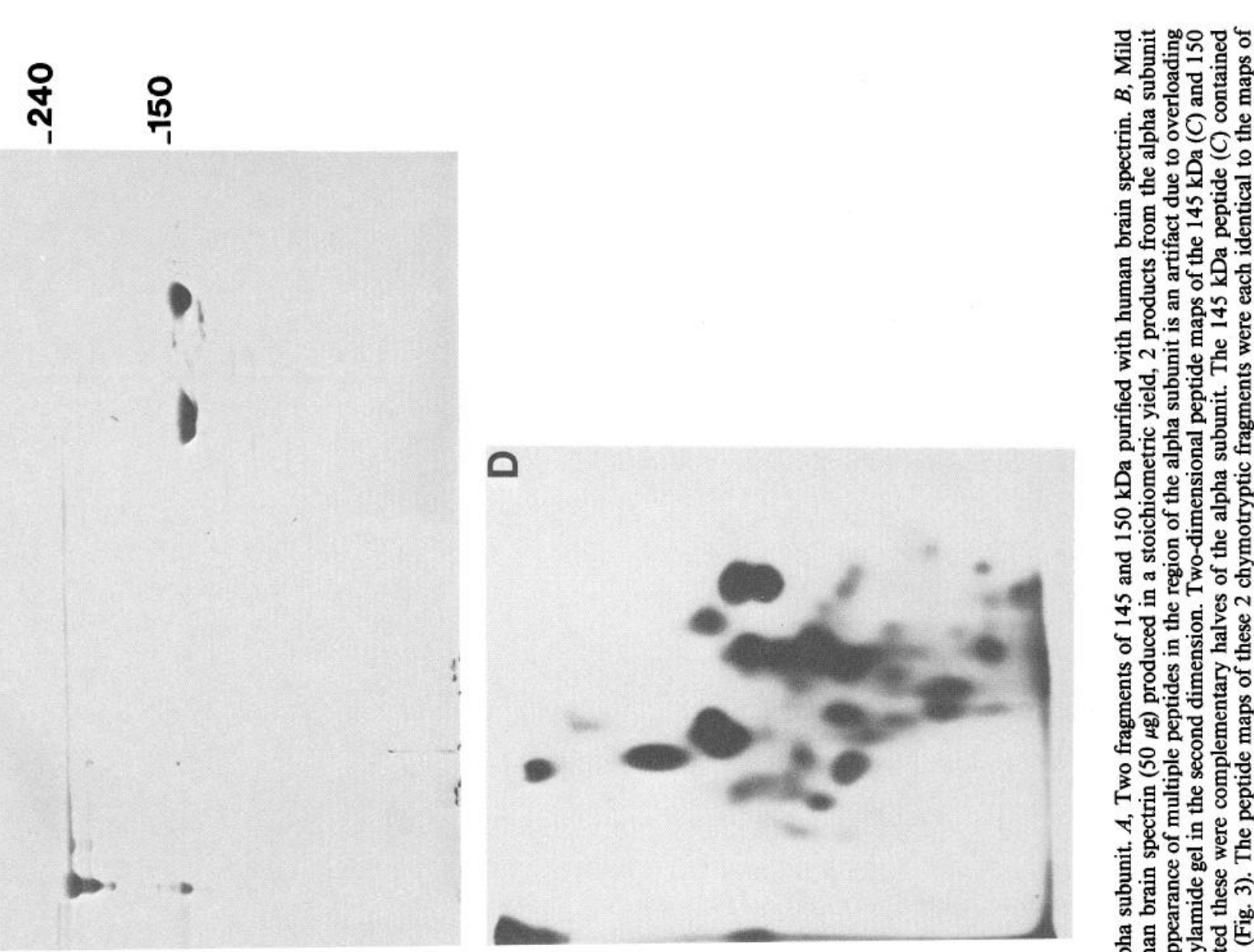

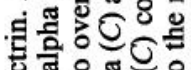
\% 9 \% क्रि

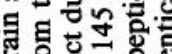
s 4 .

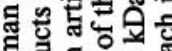
寻 등

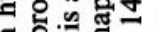
可先目 政 ठ屯 5 和 政

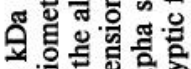

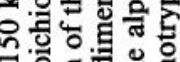
过

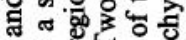
․ㅖ 낭 $\checkmark$ 马. o .5 .5

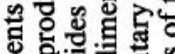

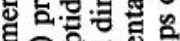

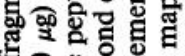
을.

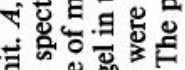
. के $m$

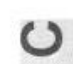

U

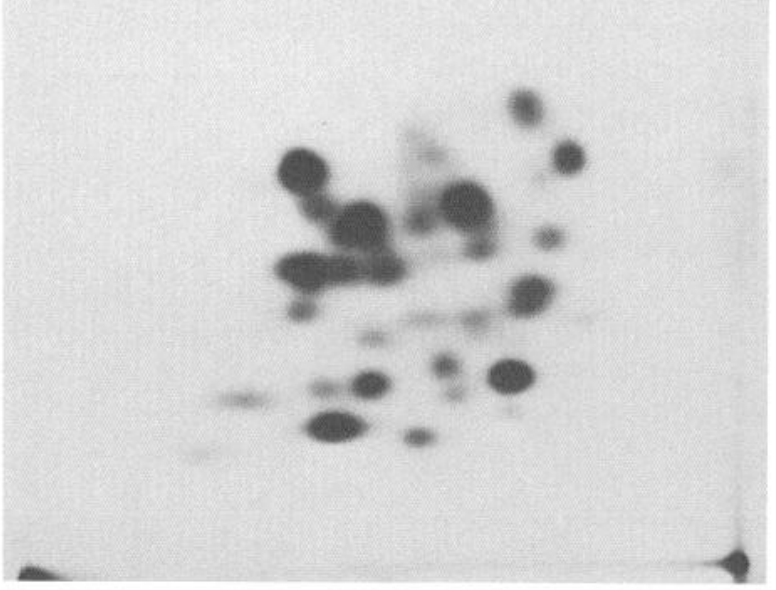

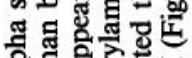
त

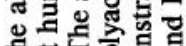
势 웡

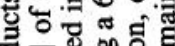
둥

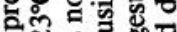
글 ․ㅖㄹ 政 은

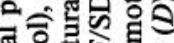
열 至

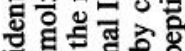
造 a

$\checkmark$ 뜰

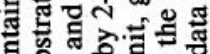
8 눙 E है 元 , 정 ए छ्ठ 땡.을 击

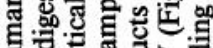

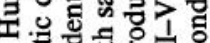
2. 응

政

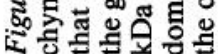


The linear order of the peptides was determined from a series of overlapping peptides generated by alternative cleavage techniques, either enzymatic or chemical. Large peptides (approximately $150 \mathrm{kDa}$ ) containing domains I-II and III-V are present as natural contaminants of the purified brain spectrin (see below). Peptide mapping of these fragments allowed the assignment of the linear order of domains III-V. However, due to a proteolytically hypersensitive site near the center of the molecule (see below), fragments bridging this region could not be generated by any of the enzymatic methods employed. Chemical cleavage of the molecule with NTCB yielded several overlap peptides that contained all or parts of the domains defined by trypsin digestion. Specifically, NTCB cleavage yielded a peptide of $70 \mathrm{kDa}$ that contained most of domain III and one-half of domain IV (Fig. $4 B$ ), while another NTCB peptide of $45 \mathrm{kDa}$ contained parts of domains II and III (Fig. 4C). This combination of overlap peptides containing domains I-II, II-III, IIIIV, and III-V allowed the linear alignment of the domains within the alpha subunit as depicted in Figure 9.

\section{Brain alpha spectrin contains a proteolytically hypersensitive site near the center of the molecule}

Cleavage of the molecule with either calcium-dependent protease (CDP I and II), TPCK-trypsin, endoprotease Lys-C, $S$. aureus V-8 endoprotease Glu-C (both Glu and Glu, Asp activating conditions), and alpha-chymotrypsin invariably cleaved the alpha-subunit into 2 halves, between domains II and III. An example of this cleavage for CDP I and for chymotrypsin is shown in Figure 5. This proteolytically hypersensitive site was the first clcavage made by these protcases (Fig. 5). Clcavage at this site was also evidenct in the proteolytic fragments coisolating with the purified brain spectrin (see below). This hypersensitive site is a unique feature of alpha brain spectrin, since digestion of human erythrocyte spectrin with either trypsin, chymotrypsin, or the calcium-dependent proteases failed to generate similar fragments (Speicher et al., 1982; Croall et al., 1986).

Cleavage at the proteolytically hypersensitive site in brain alpha spectrin accounts for the 2 naturally occurring fragments Isolated human brain spectrin was contaminated with a significant proportion of proteolytic products of $145-150 \mathrm{kDa}$ (Figs. $5,6 \mathrm{~A}$ ). Similar products are present in brain tissue from other species, but are more abundant in the human material. Their presence was not due to the method of preparation since bovine brain spectrin isolated by the same procedure showed significantly less contamination by these proteolytic products (Fig. 5). Although previous reports have demonstrated immunologic cross-reactivity between these prominent fragments and the alpha-subunit (Glenney et al., 1982; Davis and Bennett, 1983; Carlin et al., 1983; Harris et al., 1985), their relationship to the parent subunit has not been clear. Two-dimensional IEF/SDSPAGE of purified human brain spectrin (Fig. $6 \mathrm{~A}$ ) demonstrated the presence of 2 fragments of similar molecular weight with isoelectric points of 5.6 and 5.2, making it unlikely that these peptides were derived from one another via a precursor-product mechanism. Digestion of brain spectrin with small amounts of chymotrypsin [enzyme: substrate, 1:125 to $1: 500$ (mol:mol), $\left.23^{\circ} \mathrm{C}, 15 \mathrm{~min}\right]$ resulted in the generation of 2 fragments whose molecular weights and isoelectric points were nearly indistinguishable from the naturally occurring peptides (Fig. 6, $A$ and $B$; see also Fig. 5). Coincident with the appearance of these 2 fragments was the stoichiometric disappearance of the alpha-

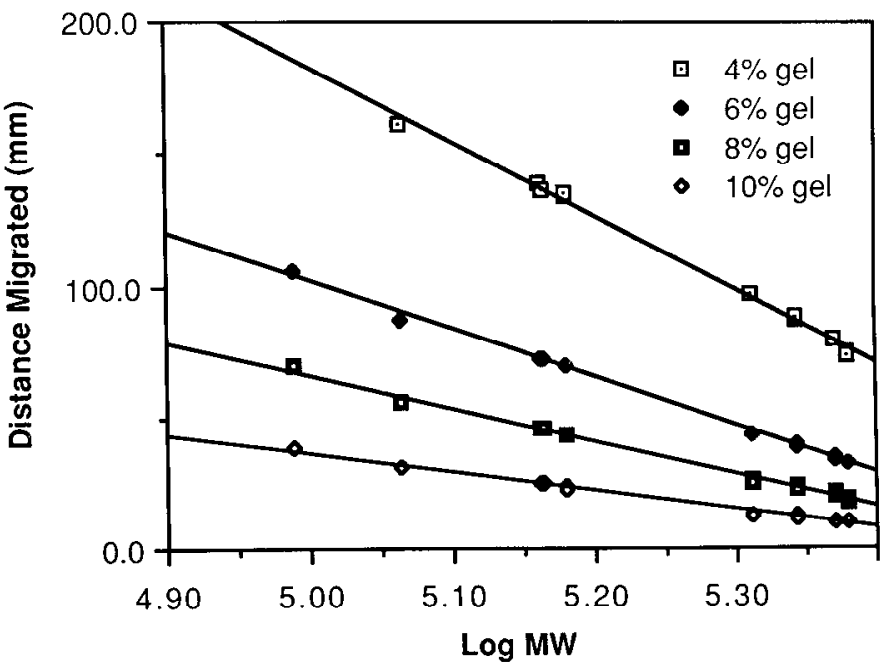

Figure 7. The complementary halves of the alpha-subunit, whether endogenous or generated with chymotryptic digestion, migrated with apparent molecular weights of 145 and $150 \mathrm{kDa}$ on SDS-PAGE using a discontinuous buffer system (Laemmli, 1970). The apparent molecular weights of the proteolytic products were estimated by a least-squares regression analysis based in the accepted apparent molecular weights of several proteins. The alpha-subunit of both human brain and erythrocyte spectrin migrated with an apparent molecular weight of $240 \mathrm{kDa}$. The standard proteins used, with their reported molecular weights were phosphorylase B $(94 \mathrm{kDa})$, beta-galactosidase $(116 \mathrm{kDa})$, myosin heavy chain $(205 \mathrm{kDa})$, and laminin light subunit $(220 \mathrm{kDa})$. Human erythrocyte beta spectrin $(220 \mathrm{kDa})$ and human brain beta spectrin $(235 \mathrm{kDa})$ were also included in the analysis since they fell on the curve defined by the other standards. All of the standard curves had $r$ values $>0.99$.

subunit. Peptide maps of the fragments generated by chymotryptic digestion of the isolated alpha-subunit (Fig. 6, $C$ and $D$ ) or of the fragments co-isolated with the intact molecule (data not shown) demonstrated that these were complementary halves of the alpha-subunit. Additional experiments utilizing chymotrypsin under very mild digestion conditions [enzyme: substrate, $1: 125(\mathrm{~mol}: \mathrm{mol}), 23^{\circ} \mathrm{C}, 5-300 \mathrm{sec}$ yielded only the 145 and $150 \mathrm{kDa}$ peptides, even when care was taken to prevent the loss of small peptides during fixation (data not shown). These experiments further documented the extreme sensitivity of brain alpha spectrin to proteolytic cleavage between domains II and III near the middle of the molecule.

The peptides generated by enzymatic digestion of the alphasubunit at the hypersensitive site migrate in both 1- and 2-dimensional polyacrylamide gels with apparent molecular weights of 145 and $150 \mathrm{kDa}$, in spite of the fact that their aggregate apparent mass was greater than the apparent mass of the brain spectrin alpha-subunit $(240 \mathrm{kDa})$. This behavior was found to be independent of the acrylamide concentration of the gel (Fig. 7). It is not apparent from these experiments whether there is anomalous migration of the intact alpha-subunit and/ or one or both of the peptides, although anomalous migration on SDS-PAGE of alpha spectrin derived peptides has been previously noted (Glenney et al., 1983).

\section{Calmodulin binds to a region at or near the hypersensitive site}

Alpha brain spectrin has been identified as the site of calmodulin binding in the nonerythroid spectrins, using both gel overlay (Glenney et al., 1983; Harris et al., 1985) and affinity chromatography (Glenney and Weber, 1985) techniques. From these studies, it was apparent that at least one of the $145-150 \mathrm{kDa}$ 


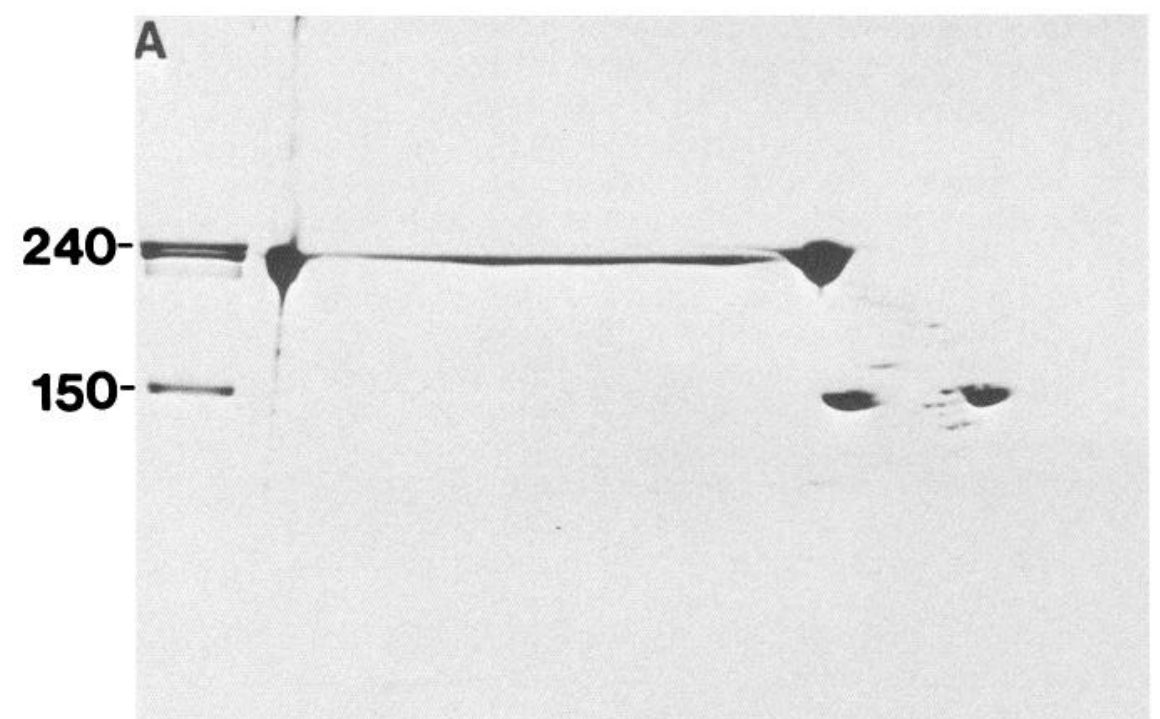

B

Figure 8. Calmodulin binds with high affinity to the intact alpha-subunit and to the $145 \mathrm{kDa}$ proteolytic product containing domains III-V. $A$, Two-dimensional IEF/SDS-PAGE of isolated purified human brain spectrin. The alpha-subunit is represented by a single discrete spot, as are its 2 major proteolytic products, but the beta-subunit is aggregated and streaked in the IEF dimension. Coomassie blue stain of a $6 \%$ gel. $B$, Calmodulin overlay of an identical gel demonstrating strong binding to the alpha-subunit and to the $145 \mathrm{kDa}$ proteolytic product (domains III-V). Weak binding to the $150 \mathrm{kDa}$ proteolytic product (domains I-II) is also evident. The other peptides binding calmodulin are precursors of the $145 \mathrm{kDa}$ product as determined by 2 -dimensional peptide mapping. Autoradiogram of an 8 hour exposure with ${ }_{125}$ I-labeled bovine brain calmodulin.

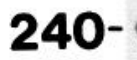

$150-\cdots$ natural products retained calmodulin binding activity (Harris et al., 1985). As shown in Figure 8, it appears that the calmodulin binding site is primarily resident in the $145 \mathrm{kDa}$ natural product containing domains III-V but must be very close to, and may even bridge, the hypersensitive region since very weak binding is seen in the $150 \mathrm{kDa}$ peptide containing domains I-II. A similar $145 \mathrm{kDa}$ fragment generated by chymotrypsin and $\mathrm{V}-8$ protease also retains caimodulin binding, but no fragments retain calmodulin binding after tryptic digestion (data not shown). However, the NTCB-generated fragment that mapped to the center of the molecule and bridge domains II and III (Fig. $4 C$ ) did bind calmodulin as determined using the gel overlay technique (data not shown). Thus, a calmodulin binding domain is located very close to the center of the alpha subunit, and it is probably intimately associated with the proteolytically hypersensitive site.

\section{Discussion}

Human brain alpha spectrin (fodrin) has been shown to contain a hypersensitive region in almost the precise center of the mol- ecule, which is the favored site of action of several proteases both in vitro and in vivo. The site of calmodulin binding is also located near this region. The identification of this region has been facilitated by the determination of the proteolytically resistant domain structure of alpha fodrin. The alpha-subunit is comprised of 5 unique domains ranging from 11 to $108 \mathrm{kDa}$. The unique nature of these domains, the identification of overlapping peptides, and the linear order of the domains within the parent protein have been determined by 2-dimensional peptide mapping. A model summarizing these data is shown in Figure 9. The domain structure shown is reminiscent of, but distinct from, that determined for erythrocyte spectrin (Morrow et al., 1980; Speicher et al., 1982).

Mild tryptic digestion was used to determine the domain structure. Tryptic digestion of proteins is inherently sensitive to both the frequency of Arg and Lys residues and the secondary, tertiary, and quaternary structure of the molecule (i.e., the degree of availability of the residues to the protease). Since Lys and Arg are found in great abundance in brain spectrin, averaging 1 out of 7 residues (Harris et al., 1985), cleavage under the mild 


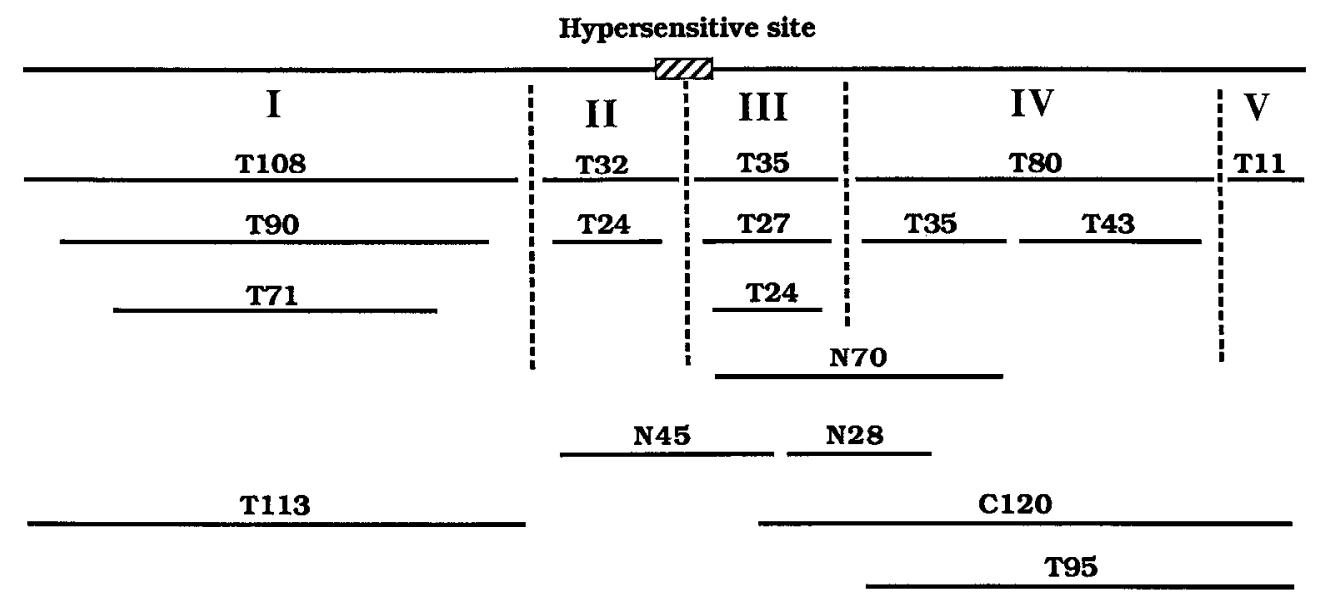

(CDP, T, C, V 150)

(CDP, T, C, V 145)

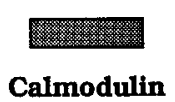

Figure 9. Summary and model of human brain alpha spectrin (fodrin) and the proteolytically defined domains as determined in Figures 2-6. The domains are labeled with Roman numerals, and the peptides are labeled according to the method of their preparation followed by their apparent molecular weights in kilodaltons. Peptides generated by trypsin digestion are designated " $\mathrm{T}$ "; " $\mathrm{N}$ " designates peptides generated by NTCB cleavage; " $C$ " is for peptides generated by chymotrypsin digestion; and "V" is for peptides generated by $S$. aureus V-8 endoprotease Glu-C digestion. CDP indicates proteolytic products found in the purified material, presumably generated by the calcium-dependent proteases, and products that were generated in vitro with the calcium-dependent proteases. The most prominent proteolytic products from each domain are also depicted. Overlapping peptides used in the alignment are indicated below the domain peptides. The hypersensitive site is located between domains II and III near the center of the molecule. The calmodulin binding site has been localized to a region near the hypersensitive site since the NTCB $45 \mathrm{kDa}$ peptide binds calmodulin, but no tryptic fragments retain the ability to bind calmodulin. The model is presented with the amino terminus on the left (see Discussion).

conditions used here is limited primarily by the accessibility of these residues.

Previous work on mapping of porcine brain spectrin used monoclonal antibodies to identify peptide fragments after enzymatic digestion (Glenney et al., 1983). These workers proposcd that the molecule was a tetramer with a head-to-head association of heterodimers similar to erythrocyte spectrin. This conclusion was based on the reactivity and orientation of several monoclonal antibodies observed by electron microscopy after rotary shadowing. They also observed that mild tryptic digestion generated 2 peptides from the alpha-subunit of 140 and 145 $\mathrm{kDa}$. With prolonged digestion, these 2 peptides lost their reactivity to all but one antibody, and the molecular weights of the final products were 85 and $110 \mathrm{kDa}$, respectively. These cascades can now be put into the context of the domain structure reported here, their $85 \mathrm{kDa}$ fragment corresponds to domain IV and their $110 \mathrm{kDa}$ fragment to domain I. In conjunction with their data it is likely that the $\mathrm{NH}_{2}$ terminus of brain alpha spectrin is at the center of the tetramer, analogous to human erythrocyte spectrin (Morrow et al., 1980; Speicher and Marchesi, 1984).

One of the more interesting properties of human brain alpha spectrin is the centrally located proteolytically hypersensitive site. As previously mentioned, all proteases tested cleaved preferentially at this site. The amino acid peptide bonds that these proteases cleaved included Lys, Arg, Phe, Tyr, Trp, Glu, and Asp. This wide assortment of amino acid residues indicates a site of no particular charge or hydrophobic character, but rather a region highly accessible to enzymatic cleavage. Interestingly, the site appears to be either more exposed in the human material, or the enzymes responsible for the cleavage of the mol- ecule are more active. Preliminary experiments suggest that the quantity of alpha fodrin processed at the hypersensitive site is not simply related to the postmortem interval. When material removed during therapeutic temporal lobectomy was examined without delay, approximately $15 \%$ of the alpha fodrin was found to be proccssed, an amount comparable to that found in matcrial isolated from cadaver donors. This result suggests that these products are preexistent in situ, and the time of removal or quick freezing of the brain material is not the most important factor determining the generation of these proteolytic products.

Recently, it has been proposed that proteolysis of brain spectrin in part controls the expression of glutamate receptors in neuronal synapses, an important step in the generation and storage of memory (Lynch and Baudry, 1984). Incubation of hippocampal slices in increased concentrations of calcium stimulated the binding of glutamate and simultaneously enhanced the proteolysis of brain spectrin (Baudry et al., 1983). Siman et al. (1984) demonstrated that brain spectrin was a substrate for calcium-dependent protease I in vitro and that it was a preferred substrate in situ. Both the increased glutamate binding and the proteolysis of brain spectrin could be blocked by leupeptin (a specific inhibitor of the calcium-dependent proteases) or by anti-brain spectrin antibodies (Siman et al., 1985). Our results indicate that the likely site of this cleavage event is between domains II and III at the proteolytically hypersensitive site. Conversely, our results do not indicate that the proteolysis of brain spectrin in vitro to peptides of $145-150 \mathrm{kDa}$ is a multistep process (Siman et al., 1985).

The identification of a calmodulin binding site near or at the hypersensitive region also raises the interesting possibility that 2 levels of calcium-dependent control over fodrin processing 
and/or function may be operative: (1) at the level of the calciumdependent protease and (2) at the level of calmodulin-fodrin interaction. Our preliminary cvidence suggests that calmodulin does alter the protease sensitivity of the hypersensitive site in a calcium-dependent manner (A. S. Harris and I. S. Morrow, unpublished observations). Beyond this, the effect of the proteolytic cleavage or of calmodulin binding to brain spectrin remains to be determined. It is important to note that calmodulin binds to a different location in brain spectrin than in human ery throcyte spectrin (Anderson and Morrow, 1987), the implications of which are presently uncertain.

Finally, several studies have indicated spectrin exists in multiple isoforms in a variety of tissues. The most thoroughly investigated tissues are those from the chicken (Lazarides and Nelson, 1983, 1985; Nelson and Lazarides, 1983; Lazarides et al., 1984), where multiple isoforms have been found in both muscle and nervous tissue. The avian system may be unique in that all spectrins isolated have a common alpha-subunit, regardless of the tissue of origin. This situation is not found in mammals. Spectrin isoforms have been identified in mammalian muscle tissue (Shile et al., 1985; Bloch and Morrow, 1987) and brain tissue (Riederer et al., 1986; Siman et al., 1987). These studies have raised the possibility of multiple spectrin isoforms with different alpha- and beta-subunits. The spectrin used in the studies reported here was purified from a membrane fraction of a brain homogenate. Similar fractions have been found to contain only 240:235 spectrin (Siman et al., 1987). Therefore, it is likely that our preparations are homogeneous. In addition, we have sequenced 3 different regions of the molecule and did not find evidence of isoforms in those sequences (A. S. Harris, S. Keithan, D. W. Speicher, and J. S. Morrow, unpublished observations). Our preparations appeared homogeneous by 2-dimensional IEF/SDS-PAGE, if precautions were taken to avoid overload artifacts (data not shown). Finally, extensive peptide mapping of approximately 8 preparations of human brain spectrin, using low and high salt extractions, has never yiclded evidence of isoforms in our preparations. Therefore, isoforms of brain spectrin do not appear to be a contributing factor in the current study.

Note added in proof: After the submission of this manuscript, it came to our attention that an independent study demonstrating an effect of calmodulin on the proteolysis of fodrin had appeared (Seubert et al., 1987). The results reported here provide a clear structural basis for those findings.

\section{References}

Anderson, J. P., and J.S. Morrow (1987) The interaction of calmodulin with human erythrocyte spectrin. J. Biol. Chem. 262: 6365-6372.

Baines, A. J., and V. Bennett (1985) Synapsin I is a spectrin-binding protein immunologically related to erythrocyte protein 4.1 . Nature 315: 410-413.

Baudry, M., R. Siman, E. K. Smith, and G. Lynch (1983) Regulation by calcium ions of glutamate receptor binding in hippocampal slices. Eur. J. Pharmacol. 90:161-168.

Bennett, V. (1985) The membrane skeleton of human erythrocytes and its implications for more complex cells. Annu. Rev. Biochem. 54: 273-304.

Birkenmeier, C. S., D. M. Bodine, E. A. Repasky, D. M. Helfman, S. H. Hughes, and J. E. Barker (1985) Remarkable homology among the internal repeats of erythroid spectrin. Proc. Natl. Acad. Sci. USA 82: $5671-5675$.

Bloch, R. J., and J.S. Morrow (1987) A unique beta-spectrin associated with clustered acetylcholine receptors. J. Cell Biol. 105: 290a.
Burgess, W. H., D. K. Jemiolo, and R. H. Kretsinger (1980) Interaction of calcium and calmodulin in the presence of sodium dodecyl sulfate. Biochim. Biophys. Acta 623: 257-270.

Carlin, R. K., D. C. Bartelt, and P. Siekevitz (1983) Identification of fodrin as a major calmodulin-binding protein in postsynaptic density preparations. J. Cell Biol. 96: 443-448.

Croall, D. E., J. S. Morrow, and G. N. DeMartino (1986) Limited proteolysis of the erythrocyte membrane skeleton by calcium-dependent proteases. Biochim. Biophys. Acta 882: 287-296.

Curtis, P. J., A. Palumbo, J. Ming, P. Fraser, L. Cioe, P. Meo, S. Shane, and G. Rovera (1985) Sequence comparison of human and murine erythrocyte alpha-spectrin cDNA. Gene 36: 357-362.

Davis, J. Q., and V. Bennett (1983) Brain spectrin: Isolation of subunits and formation of hybrids with erythrocyte spectrin subunits. $J$. Biol. Chem. 258: 7757-7766.

Elder, J. H., R. A. Pickett, II, J. Hampton, and R. A. Lerner (1977) Radioiodination of proteins in single polyacrylamide gel slices. J. Biol. Chem. 252: 6510-6516.

Eshdat, Y., and A. Lemay (1979) Specific fragmentation of human erythrocyte spectrin by chemical cleavages at cysteine residues. Biochim. Biophys. Acta 577: 360-370.

Fach, B. L., S. F. Graham, and R. A. B. Keates (1985) Association of fodrin with brain microtubules. Can. J. Biochem. Cell Biol. 63: 372381.

Glenney, J. R., Jr., and K. Weber (1985) Separation of fodrin subunits by affinity chromatography on calmodulin-Sepharose. Anal. Biochem. 150:364-368.

Glenney, J. R., Jr., P. Glenney, M. Osborn, and K. Weber (1982) An $\mathrm{f}$-actin and calmodulin-binding protein from isolated intestinal brush borders has a morphology related to spectrin. Cell 28: 843-854.

Glenney, J. R., Jr., P. Glenney, and K. Weber (1983) Mapping the fodrin molecule with monoclonal antibodies. J. Mol. Biol. 167: 275293.

Goodman, S. R., and I. S. Zagon (1984) Brain spectrin: A review. Brain Res. Bull. 13: 813-832.

Goodman, S. R., I. S. Zagon, C. F. Whitfield, L. A. Casoria, S. B. Shohet, S. E. Brestein, P. J. McLaughlin, and T. L. Laskiewicz (1984) A spectrin-like protein from mouse brain membranes: Phosphorylation of the 235,000 dalton subunit. Am. J. Physiol. 16: C61-C73.

Harris, A. S., L. A. D. Green, K. J. Ainger, and J. S. Morrow (1985) Mechanism of cytoskeletal regulation (I): Functional differences correlate with antigenic dissimilarity in human brain and erythrocyte spectrin. Biochim. Biophys. Acta 830: 147-158.

Harris, A. S., J. P. Anderson, P. D. Yurchenco, L. A. D. Green, K. J. Ainger, and J. S. Morrow (1986) Mechanisms of cytoskeletal regulation: Functional and antigenic diversity in human erythrocyte and brain beta spectrin. J. Cell. Biochem. 30: 51-69.

Ishikawa, M., H. Murofushi, and H. Sakai (1983) Bundling of microtubules in vitro by fodrin. J. Biochem. 94: 1209-1217.

Laemmli, U. K. (1970) Cleavage of structural proteins during the assembly of the head of bacteriophage $T_{4}$. Nature 227:680-685.

Lazarides, E., and W. J. Nelson (1983) Erythrocyte and brain forms of spectrin in cerebellum: Distinct membrane cytoskeletal domains in neurons. Science 220: 1295-1296.

Lazarides, E., and W. J. Nelson (1985) Expression and assembly of the erythroid membrane-skeletal proteins ankyrin (globlin) and spectrin in the morphogenesis of chicken neurons. J. Cell. Biochem. 27: $423-441$.

Lazarides, E., W. J. Nelson, and T. Kasamatsu (1984) Segregation of two spectrin forms in the chicken optic system: A mechanism for establishing restricted membrane-cytoskeletal domains in neurons. Cell 36: 269-278.

Lowry, O. H., N. J. Rosenbrough, A. L. Farr, and J. Randall (1951) Protein measurement with the Folin phenol reagent. J. Biol. Chem. 193: 265-275.

Lynch, G., and M. Baudry (1984) The biochemistry of memory: A new and specific hypothesis. Science 224: 1057-1063.

Marchesi, V. T. (1985) Stabilizing infrastructure of cell membranes. Annu. Rev. Cell Biol. 1: 531-561.

Morrow, J. S. (1984) Spectrins: Mediators of cytoskeletal function. Am. J. Dermatopathol. 6: 573-581.

Morrow, J. S., and V. T. Marchesi (1981) Self-assembly of spectrin oligomers in vitro: A basis for a dynamic cytoskeleton. J. Cell Biol. 88: $463-468$.

Morrow, J. S., D. W. Speicher, W. J. Knowles, J. C. Hsu, and V. T. 
Marchesi (1980) Identification of functional domains of human erythrocyte spectrin. Proc. Natl. Acad. Sci. USA 77: 6592-6595.

Nelson, W. J., and E. Lazarides (1983) Switching of subunit composition of muscle spectrin during myogenesis in vitro. Nature 304:364368.

O'Farrell, P. (1975) High resolution two-dimensional electrophoresis of proteins. J. Biol. Chem. 250: 4007-4021.

Riederer, B. M., I. S. Zagon, and S. R. Goodman (1986) Brain spectrin (240/235) and brain spectrin (240/235e): Two distinct spectrin subtypes with different locations within mammalian neural cells. J. Cell Biol. 102: 2088-2097.

Seubert, P., M. Baudry, S. Dudek, and G. Lynch (1987) Calmodulin stimulates the degradation of brain spectrin by calpain. Synapse 1 : $20-24$.

Shile, P., A. S. Harris, and J. S. Morrow (1985) Human skeletal muscle contains unique tissue specific spectrin isoforms. Fed. Proc. 44: 742a.
Siman, R., M. Baudry, and G. Lynch (1984) Brain fodrin: Substrate for calpain I, an endogenous calcium-activated protease. Proc. Natl. Acad. Sci. USA 81: 3572-3576.

Siman, R., M. Baudry, and G. Lynch (1985) Regulation of glutamate receptor binding by the cytoskeletal protein fodrin. Nature $313: 225$ 228.

Siman, R., M. Ahdoot, and G. Lynch (1987) Ontogeny, compartmentation and turnover of spectrin isoforms in rat central neurons. J. Neurosci. 7: 55-64.

Speicher, D. W., and V. T. Marchesi (1984) Erythrocyte spectrin is comprised of many homologous triple helical segments. Nature 311 : 177-180.

Speicher, D. W., J. S. Morrow, W. J. Knowles, and V. T. Marchesi (1982) A structural model of human erythrocyte spectrin: Alignment of chemical and functional domains. J. Biol. Chem. 257: 9093-9101. 